\title{
"Such a mistake as I have often seen / In a play": The Duchess of Malfi, a Tragedy of Errors
}

\author{
Christine Sukic \\ Université de Reims Champagne-Ardenne, CIRLEP EA4299
}

The underlying idea of a "fault" seems to have dominated much of the critical literature devoted to John Webster's plays. Many critics, especially in the nineteenth and the first half of the $20^{\text {th }}$ century, seem to have been unable to classify Webster or to understand him as an emblematic playwright of his time. Rupert Brooke, in the short essay he wrote about Webster a couple of years before the beginning of World War I, talked of "several uncouth characteristics of his that have an effect which halts between archaism and a kind of childish awkwardness, like 'primitive' art of various nations and periods" (Brooke 126). Christina Luckyj gives more recent examples of this kind of statement among critics, such as Una EllisFermor's or Clifford Leech's condemnation of Webster's incoherence, especially in his use of sententiae (Luckyj 24). In her article entitled "The 'Impure Art' of John Webster," Inga-Stina Ekeblad writes that "Webster often leaves us in confusion," while Emrys Jones talks of "irregular passions" (Luckyj 28). ${ }^{1}$

As early as 1617, the satirist Henry Fitzgeffrey, in his Satyres: and Satyricall Epigrams, mocked Webster's social origins ("The playwright-cartwright: whether?"), but also stressed the complex and intricate aesthetics of his works, calling him "crabbed Websterio" and railing at the obscurity of his style:

Was ever man so mangled with a Poem?

See how he draws his mouth awry of late,

How he scrubs, wrings his wrists, scratches his pate!

A midwife! Help! By his brain's coitus,

Some centaur strange, some huge Bucephalus,

Or Pallas-sure engendered in his brain!

(qtd. in Webster 2015, 187) ${ }^{2}$

The exaggerations of those lines are to be read in the light of the satirical vein of the piece, but it is interesting that Fitzgeffrey should stress the monstrous and the strange, as well as the difficult style verging on the faulty ("awry"). Webster himself, in the epistle "To the reader" prefixed to his play The White Devil (1612), admitted to having written a work that did not correspond to what we would now call a classical model: "If it be objected this is no true dramatic poem, I shall easily confess it [...], willingly, and not ignorantly, in this kind have I faulted" (Webster 2008, 5). For Christina Luckyj, commenting on this epistle, "Webster aligns his play not with the compressive simplicity of classical theatre but with the episodic multiplicity of native English drama" (Webster 2008, 5, note 15).

In 1960, John Dent wrote a book entitled John Webster's Borrowing which was to have a lasting impact on critical views of John Webster. Describing the poet's style as "heavily condensed [...], often too cryptic to be readily intelligible" (Dent 20), he confirmed the

\footnotetext{
${ }^{1}$ From the title of his article, "Irregular Passions," Times Literary Supplement, 22 December 1989.

${ }^{2}$ All quotations from the play are from this edition, unless otherwise stated.
} 
idea-already found in $19^{\text {th }}$-century accounts of the playwright ${ }^{3}$ —of Webster as an irregular, imperfect playwright and poet, and one that was difficult to understand.

Dent also noted that Webster borrowed almost everything he wrote: while Shakespeare's borrowings are described as "occasional imitations," "traces, or possible traces" (Dent 52), Webster's are deemed "extraordinary" (9) and his plays "extensively built out of borrowings" (20). In fact, this practice was common to every early modern writer. Shakespeare himself borrowed all his plots, and many of his lines can be traced to either classical or nearcontemporary writers. This has never led to any questioning of his talent or "genius." Montaigne himself acknowledged borrowing freely from others and having written what may have appeared to others as "a nosegay of strange floures," with nothing personal in it "but the thred to binde them" ("Of Phisiognomy," book III, chapter 12, Montaigne 595).

It is true that The Duchess of Malfi, on a surface reading, could appear difficult to grasp because of some of its constitutive elements: the moral point of view seems to dominateseveral characters, for instance, condemn the Duchess's conduct-, while the play also stresses the moral corruption of the Duchy of Malfi. At the same time, the sense of morality is unclear, indeterminate, sometimes contradictory, or even incoherent, as in the case of Bosola, the murderer turned avenger of his own crime. The play itself combines regular blank verse and a great number of sententiae in the form of rhyming couplets, interspersed throughout the text. In fact, this sense of error or irregularity is at the core of the text: it can be read as a poetic but also a tragic feature - as the impossibility of making sense of reality. In other words, The Duchess of Malfi is a tragedy of errors that finds its context in an unstable, erratic sense of reality. As such, it is a modern tragedy, in keeping with the aesthetics of its time.

The aim here is not to render Webster clear when others see him as obscure, but to inscribe his play within the cultural context of his time in order to make sense of his aesthetics, so that Webster's "errors" do not constitute a moral judgement on his works, but are included within his own poetic art. Many critics have pointed out Webster's ambiguities in The Duchess of Malfi. While the Duchess's brothers condemn her for marrying Antonio, she also appears as a model of Stoic virtue in the sufferings that are imposed on her. As for Bosola, he comes across, from the first, as a humoral anomaly; he is both a murderer and an avenger, though he turns out to be a complete failure in this last task, and admits to having killed Antonio "unwittingly" (5.5.37). Errors, in the play, are envisaged from a moral perspective and inform Webster's depiction of a corrupt society, but more importantly, they are part of the play's aesthetics.

As we shall first see, the notion of error is given a moral meaning in the play, even though Webster does not express a moral point of view himself: the play is grounded in a-morality. Then, characters seem to err in this moral indeterminacy, in all senses of the word: they roam but also become erring characters as they succumb to humoral error-melancholy. Finally, the plot proceeds from a series of errors and chance events: tragic knowledge and tragic error are given new meanings as Webster questions literary models.

\section{"Virtue, where art thou hid?" (3.2.72): erring as essential basis of the play}

Moral errors seem to trigger and induce the plot of The Duchess of Malfi, and can even be perceived as a creative stimulus for the play. From the start, the Duchess is considered guilty, which gives an impetus to the plot, even though it is not always clear what her fault is. Webster's sources differ on this point. As Leah S. Marcus has shown, while Bandello is "quite sympathetic to the lovers" (Webster 2009, 20), William Painter followed Belleforest in blaming the Duchess for her fate and describing her as a seductress who "steppeth out of the

\footnotetext{
${ }^{3}$ On the critical perception of Webster in the nineteenth century, see Moore's Webster. The Critical Heritage.
} 
right tracte" (Webster 2009, 21). In Webster's play, the Cardinal never states his reasons for condemning the Duchess, while Ferdinand himself acknowledges that his sister is in fact "the cause" (5.5.69), a phrase that can be understood either as an acknowledgement of Ferdinand's incestuous desire for his sister, or an assertion that she is to blame for everything - which in a way, amounts to the same idea, that of her essentially faulty nature for Ferdinand. Interestingly, the words "fault" and "faulty" are used on numerous occasions in the play. In 3.1, as the Duchess attempts to claim her innocence, the passage is steeped in ambivalent notions of innocence and guilt:

\section{Duchess.}

But sir, I am to have private conference with you

About a scandalous report, is spread

Touching mine honour.

\section{Ferdinand.}

Let me be ever deaf to't:

One of Pasquil's paper bullets, court-calumny,

A pestilent air which princes' palaces

Are seldom purg'd of: yet, say that it were true,-

I pour it in your bosom-my fix'd love

Would strongly excuse, extenuate, nay, deny

Faults, were they apparent in you: go be safe

In your own innocency.

(3.1.46-55)

On the surface, Ferdinand is stating that the Duchess is innocent, but that he would still love her even if she were guilty of apparent faults. Ferdinand ends his speech with the word "innocency," but the passage is also fraught with instability, through the dominant use of epanorthosis, a figure of speech that corrects what has been said, as in lines 52-54, when Ferdinand seems to hesitate and tries to find the appropriate wording: "my fix'd love / Would strongly excuse, extenuate, nay, deny / Faults." This is confirmed after the Duchess leaves the stage and Ferdinand admits he is convinced of his sister's fault: "Her guilt treads on / Hotburning coulters" (3.1.56-57). Whatever she does, she is seen as guilty. The passage also emblematises Ferdinand's unstable language and his unpredictable character.

Webster uses both sides of the tradition which dates back to Bandello, according to which the Duchess is guilty (especially in Painter) but she is also admirable. While showing her being condemned on stage, he also condemns the accusers. This ambivalence between right and wrong is first expressed by Cariola at the end of act I but is also sustained throughout the play: "Whether the spirit of greatness, or of woman / Reign most in her, I know not, but it shows / A fearful madness" (1.1.487-9). Later, one of the two pilgrims at Loreto also expresses both sides of the argument:

Here's a strange turn of state! Who would have thought

So great a lady would have match'd herself

Unto so mean a person? yet the cardinal

Bears himself much too cruel.

(3.4.23-26)

In the space of four lines, we find both a moral criticism of the duchess, and a condemnation of the way she is being treated by her brother. Thus Webster maintains a sense of moral ambiguity. The play is not meant to have a moral significance, but establishes a sense of moral indeterminacy. 
Again, it is the Duchess's fault - and her error-that moves the plot forward at 2.1, when Bosola uses the "apricocks" in order to trick her into revealing her pregnancy. Here again, her "fault" is discovered through an unusual means, since, as many critics have noted, apricots were not particularly associated with pregnancy in the early modern period (Randall 180-1). As soon as the Duchess consumes the fruit, she is taken with various symptoms ("If they do not make me sick," 2.1.150; "This green fruit and my stomach are not friends-," 2.1.151; "O, I am in an extreme cold sweat!", 2.1.153, etc.) that Bosola immediately interprets as being signs of her pregnancy, so that the plot can go into a new direction, even though the uncovering of the Duchess's state is somewhat artificial. The apricots do not constitute undeniable evidence, but rather seem to associate the Duchess with sexual promiscuity and general immorality, since the fruit was, as Dale B.J. Randall has shown, symbolic of female sexuality and the word, in its early modern version (apricock), was definitely phallic (Randall 182-9). In spite of rather flimsy evidence, Bosola shows himself to be absolutely convinced: "there's no question but her tetchiness and most vulturous eating of the apricocks are apparent signs of breeding - " (2.2.1-2). Webster chose to move the plot forward through these artificial means without being really concerned with coherence: more than absolute certainties, he seems to have been interested in instability of meaning.

Moral condemnation of the Duchess in particular suggests that morality dominates the play alongside corruption. From the very onset of the play, corruption is denounced: Antonio immediately broaches the theme of political errors when talking about France as an exemplum of good governance, suggesting that things might be different in Amalfi, even though he speaks in generalities: "But if't chance / Some curs'd example poison't near the head, / Death and disease through the whole land spread" (1.1.13-15). Ferdinand himself admits that the court is characterised by "A pestilent air, which princes' palaces are seldom purg'd of" (3.1.50). These passages are just two examples of Webster's practice of sententiae, whereby the numerous moral errors of the play seem to be counterbalanced with moral statements interspersed throughout the text, which suggest a strong moral basis to the play-even though they can, of course, be perceived as eminently ironic. There seem to be various critical assessments of these sententiae. As David Gunby noted, many critics have found them unconvincing, even though critical assessments have been rather more positive in recent years ("General Introduction," Webster 1995, 20). Rupert Brooke himself, who thought they were too general, called them "permanent vaguenesses" (Brooke 88). The main critical point about them is that they constitute anomalies in the play, as they "do not accord easily or appropriately with the action" ("General Introduction," Webster 1995, 20). Richard Allen Cave, on the other hand, stresses the difference between reading and hearing the sententiae: "Heard in context, the effect is often of a character's seeking comfort and security in proverbial wisdom which the audience with its greater awareness of the play's action knows to be cruel illusion" (Cave 13). Cave's remark suggests that the sententiae are not necessarily there to provide meaning - and that they do not convey the author's wisdom-but that they serve as a contrasting voice to the rest of the play, including musically. More to the point, they represent a moral statement, but not moral authority: they remind us that the play is built on a moral condemnation of errors in a context of moral corruption. For that matter, Bosola is the erring character par excellence, passing judgement while committing mistakes. The sententiae thus create a contrastive effect, in the musicality of the play as well as in its moral indeterminacy.

There is certainly a creative aspect to moral errors: they help move the plot forward, since everything happens once the Duchess has been found morally guilty by her brothers. However, this dynamic process is indeterminate, as characters constantly assert their blindness, their incapacity to see and therefore to reason. Thus, the more moral errors are 
pointed out in the play, the less characters are likely to find clear moral judgement. Morality is obviously not the way forward in this play: there is, in fact, no way forward, but rather a sense of wandering, of erring without destination or purpose.

\section{"I am going into a wilderness" (1.1.349): erring in the dark}

When the Duchess, Antonio and their children try to escape, after they have been discovered by Bosola, they become erring characters in the other sense of the word err, that which is defined by the Oxford English Dictionary in its first entry as "To ramble, roam, stray, wander," a sense now considered obsolete. This aspect of their movement from one place to another is emphasised at various points in the play, especially through the repeated use of the verb "banish" in several forms. The Cardinal announces at the end of 3.3 that he will "instantly solicit the state of Ancona / To have them banish'd" (66-67), and the idea of the banishment is given visual presence since it is formally represented on stage during the dumb show in act 3 scene $4-$ a dumb show that serves a double purpose: it narrates the ceremony during which the Cardinal is disrobed then dressed as a soldier, and then shows him formally banishing the Duchess, Antonio and their three children. Many commentators have noted the spectacular possibilities of this scene, which is first visually presented to the spectators and then commented upon by the two pilgrims. As David Carnegie notes, for instance, "the action of disrobing the Cardinal and then arming him will take some time, and require a number of attendants [...]. In addition, it can be made clearly emblematic" (Carnegie 54). The two pilgrims also remark that the Cardinal wrenches the Duchess's wedding ring from her finger with great violence (3.4.35-36), which adds to the striking aspect of the scene. The importance of the banishment is further underlined by two words uttered by the Duchess, in the first line of the next scene: "Banished Ancona!" (3.5.1), a terse sentence which incidentally echoes the first line ("Banish'd!") of Webster's own The White Devil (1612).

However, banishment in the play does not mean that places are significant as such: even though we hear about place-names - the truncated name of Malfi (for Amalfi), Ancona, Naples, Loreto...- - when the Duchess leaves Malfi with her spouse and children, her journey really amounts to erring in an indeterminate place. Spatial indeterminacy suggests that wandering in the play is mainly metaphorical and that the Duchess and Antonio are in search of meaning, erring in a dual sense (wandering and making mistakes), as the poetic world of the play is difficult to grasp and built on an instability of sense.

Webster's use of the error/terror rhyme is quite telling in act 4 scene 2, after the Duchess has witnessed the dance of the madmen, and just before she is killed. Bosola rings his bell and asks her to "Listen" as he utters his dirge: "Their [fools'] life, a general mist of error, / Their death, a hideous storm of terror" (4.2.175-6). This rhyme emblematises not only the sufferings this situation causes for the characters, but also the instability of meaning in the play, which is enhanced by the elliptic aspect of the two lines.

Samuel Daniel had already used the error / terror rhyme in his sonnet sequence Delia (1592), in "Since the first look that led me to this error," 4 and it also appeared in one of Claude Paradin's emblems from Devises hérö̈ques (Lyon, 1557), translated into English and published in 1591 under the title The Heroicall Devices. The emblem takes Hannibal as an

\footnotetext{
${ }^{4}$ Since the first looke that led me to this error,

To this thoughts-maze, to my confusion tending:

Still have I liv'd in griefe, in hope, in terror,

The circle of my sorrowes never ending.

(Daniel 19)

Though the sonnet is numbered XVII in Sprague's edition, it sometimes appears as sonnet XVIII.
} 
example of a great warrior who, in a situation of danger, manages to turn a dire situation to his advantage, by frightening his enemies with a clever device- "he tied firebrands to the heads of his oxen in the night season" ("Terror \& error. Feare and terror," Paradin 216). Thus, the terror / error rhyme shows the proximity of the two notions: terror is a consequence of error (the lookers-on being fooled by Hannibal's device) but error can also be a consequence of terror (they are afraid and thus misinterpret what they see). It also points to the instability of appearances, which is one of the characteristics of the play, in which familiar objects or characters suddenly turn into frightening dramatic signs. The beginning of the fourth act is one of these moments, when the Duchess is subjected to several spectacular shows, such as the dance of the madmen. Ferdinand also has wax figures of Antonio and their children presented to her, so that she imagines that they are dead (4.1.55). The Duchess's mistake is part of Ferdinand's strategy of playing with her sense of sight:

Excellent, as I would wish: she's plagu'd in art.

These presentations are but fram'd in wax

By the curious master in that quality,

Vincentio Lauriola, and she takes them

For true substantial bodies.

(4.1 108-12)

Interestingly, Webster uses the topos of "art" as a process of illusion and deception, playing on the double meaning of "art," since it can also be understood as ruse. The mention of an actual "curious master," "Vincentio Lauriola," seems, at first sight, to give more weight to the assertion, but it also negates it since this particular master seems to have been invented by Webster. ${ }^{5}$ More generally, Webster insists on the unreliability of the sense of sight throughout the play, and outward appearances are almost always deceptive. Bosola, who is a master dissimulator, gives an example which contradicts the idea of physiognomy:

There's no more credit to be given to th' face,

Than to a sick man's urine, which some call,

The physician's whore, because she cozens him.

$(1.1 .229-31)$

In other words, it is easy to make mistakes by judging from appearances, since they never reflect the inner being. In his statement, Bosola goes against the accepted idea of physiognomy - a popular form of knowledge in the early modern period, based on what Foucault called "the semantic web of resemblance" (Foucault 20). It informed perceptions of a world held to be ordered analogously in every field of thought. However, as Foucault also showed, ${ }^{6}$ this analogical vision was very much questioned in the early modern period, especially in the $17^{\text {th }}$ century. Webster partakes of this epistemological shift whereby appearances are not to be trusted. As we see in this example, Bosola associates the discrepancy between substance and appearance with disease and corruption (see Rieger 61), as if the unreliability of reality had compromised its very nature, and corrupted its very

\footnotetext{
${ }^{5}$ Several critics have pointed out that the possible model for this passage might be found in the attribution of Hermione's statue in Shakespeare's Winter's Tale to Giulio Romano. However, while Romano was an actual artist, Webster seems to have invented the artist. For Margaret E. Owens, Shakespeare and Webster have opposite purposes, since Shakespeare "cultivates indeterminacy" while "Webster's trajectory is to guide the audience toward certainty: to the understanding that within the fictive frame of the play, the truth of the spectacle is that the bodies are inorganic" (Owens 862). In other words, this passage can be understood mainly as a display of fictionality, thus reinforcing the ineffable aspect of the reality of the play and the difficulty for the main characters to grasp it and their place in their world.

${ }^{6}$ Talking about Don Quixote, Foucault writes: "writing has ceased to be the prose of the world; resemblances and signs have dissolved their former alliance; similitudes have become deceptive and verge upon the visionary or madness" (53).
} 
essence. The same comment could be made about his remarks to the Old Lady in act 2 scene 1 when he ponders on "A rotten and dead body" that is hidden "in rich tissue" (2.1.57-58). If, as Leah S. Marcus writes, this image alludes to "the Christian doctrine of the "corruption of the flesh" (Webster 2009, 174, notes 62-63), which is based on a postlapsarian vision of the world, it also suggests an aesthetic discrepancy between the inner and the outer, and indicates that reality is fundamentally unknowable, being open to errors of judgement, or mistakes. ${ }^{7}$ Thus, the Duchess is deceived by Bosola's apparent benevolence and makes the mistake of confiding in him: "Sir, your direction / Shall lead me, by the hand" (3.2.299-300). As the expression "to be in good hands" makes clear, the hand is usually associated with trustworthiness and reliability. The physician and philosopher John Bulwer, in his famous book Chirologia, or the Natural Language of the Hand (1644), stated that the hand, through gesture, is "a great discoverer of dissimulation" (Bulwer sig. A5v); and indeed, chiromancy (or palmistry), quite popular in the early modern period, is a form of physiognomy that purports to reveal a person's character by looking at the lines of their hands. ${ }^{8}$ However, in the play, the trustworthiness of the hand - a body part that is mentioned extensively ${ }^{9}$-is reversed. Ironically, the Duchess's trust in Bosola appears as an inverted image when Ferdinand gives her a dead man's hand to kiss in act 4, scene 1 (43-45). Again, she is tricked by her brother into making a mistake, taking the "dead man's hand" (4.1.54) for his own.

The unreliable and illusory aspect of appearances is reinforced by the use of theatrical metaphors, interspersed throughout the play, as when the Duchess describes the world as "a tedious theatre" (4.1.81), or when Bosola calls himself an "actor" (5.5.83), or tells of his own killing of Antonio as "such a mistake as I have often seen / In a play" (5.5.93-94). Erring finally culminates in act 5, scenes 4 and 5, which take place "i'th'dark" (5.4.36), the perfect setting for mistakes to occur, especially Bosola's "direful misprision" (5.4.77) or "mistake" (5.5.93) of stabbing Antonio, "The man [he] would have sav'd'bove [his] own life" (5.4.51). They are also made up of a series of asides and threats uttered in soliloquies, as if reality was undergoing fragmentation. As for act 5 scene 5, it is based on a misunderstanding, since the Cardinal is the victim of a mistake: not wanting the gentlemen of his entourage to know about Ferdinand's folly, he tells them that he might cry for help in order to test their obedience but that they must on no account intervene; of course, when he really cries for help, they think he is faking an attack - "Fie upon his counterfeiting," one of them says (5.5.20). The play thus ends on the suggestion that the plot unfolds through the chance mistakes of some of the characters.

If characters err and seem to roam the stage, it is also because of their melancholy, which is another type of error. Melancholy erring appears even from the first, when the Duchess admits to Cariola that she is "going into a wilderness / Where [she] shall find nor path, nor friendly clew/ To be [her] guide" (1.1.349-51). The word "wilderness" has religious connotations with the reference to Numbers 14.33, but here it is also a metaphor of the Duchess's loneliness and helplessness, and it was often associated with melancholy at the time. ${ }^{10}$ Robert Burton, in The Anatomy of Melancholy (1621), describes the world as "a maze,

\footnotetext{
${ }^{7}$ According to the Oxford English Dictionary, a mistake is primarily a "misconception about the meaning of something" or an "error of judgement" (first entry), while an error, apart from the sense of "roaming" already mentioned here, can be a mistake, but also "A departure from moral rectitude; a transgression, wrong-doing." It seems that a mistake is more often involuntary, whereas an error has a moral basis.

${ }^{8}$ On chiromancy as one of the branches of physiognomy, see Porter 88.

${ }^{9}$ Albert H. Tricomi devoted an article to the subject of "The Severed Hand in Webster's Duchess of Malfi" (Tricomi). The play also appears in Katherine Rowe's book, Dead Hands, especially Chapter 3, "'That Curious Engine': Action at a Distance in The Duchess of Malfi" (Rowe 86-110).

${ }^{10}$ See for instance Richard Brome, The Antipodes (1640), when Barbara Blaze describes Perigrine's melancholy and says that "his mind / Is in a wilderness." (1.3.21-22)
} 
a labyrinth of errors, a desert, a wilderness" (Burton 236). Melancholy is indeed the sign of an error, according to the theory of humours, since it suggests a sense of excess, as opposed to the Galenic model of the balance of the four humours.

There are several melancholy characters in this play of errors, Bosola being the most emblematic: his "black melancholy" (1.1.73) has turned him into an unreliable, constantly dissatisfied character-one of the "black malcontents" mentioned at 1.1.78, who have turned melancholy through lack of action. Finally, he becomes a murderer who does his duty only to turn against his master in order to avenge the murder that he himself has committed, as if he wanted to correct his mistake. As an avenger, he is no better, since he kills Antonio by mistake. From the first, he is described as faulty: he "[w]ould be as lecherous, covetous, or proud, / Bloody, or envious, as any man, / If he had means to be so" (1.1.26-28).

Melancholic excess becomes the norm: the play is pervaded with a strong sense of humoral anomaly that affects all characters. The Cardinal is "a melancholy churchman" (1.1.151-2), and if we are to believe Ferdinand, the Duchess herself is affected: "Her melancholy seems to be fortifi'd / With a strange disdain" (4.1.11-12). Antonio uses the word for himself at the beginning of the play: "My banishment, feeding my melancholy" (1.1.387). As for Ferdinand, the Doctor defines his disease as a form of melancholy. When Pescara asks him what lycanthropy is, he answers, "In those that are possessed with't there o'erflows / Such melancholy humor they imagine / Themselves to be transformed into wolves" (5.2 8-10). His affection also causes him to wander in churchyards (5.2.11), even thinking that he is being followed by his shadow (5.2.35) and thus evoking the image of a wandering, erring character, trying to escape his own self. The overwhelming presence of melancholy - and of disease in general-confirms the image used by Antonio at the beginning of the play, about a prince's court that could be contaminated "if"t chance / Some cursed example poison't near the head" (1.1.13-14). Like the ruling family, the whole state seems to be affected by an anomaly, a fundamental error. As Ferdinand suggests, "It is some sin in us" (2.5.65) - a line which could express a sort of hereditary curse on the family, but also the idea that error affects everyone in a postlapsarian state. The world of the play, and every dimension of its context, errs, thus adding instability and preventing the Duchess from grasping reality. Making errors can even be seen as ontological in a play which can be defined as a tragedy of errors.

\section{“The stars' tennis balls" (5.4.52): a tragedy of errors}

The play unfolds as a series of tragic accidents, the most characteristic of which is probably Bosola's killing of Antonio, as if the plot itself were erring, and not following a linear direction. The reason for this is that there is no sense of fate or providence in the play-and no poetic justice either - but rather a series of tragic episodes based on an indeterminate sense of chance. As we have seen, meaning seems to be jeopardised, and characters roam endlessly in a melancholy state, looking for directions but never finding them. Even the tragic flaw is absent since the plot unfolds through the fits and starts of melancholy, while the starting-point of the plot - the two brothers deciding that their sister is guilty - is never really made clear. The play is indeed a series of situations in which characters are fooled by appearances and are unable to act in a rational way, like Julia, the "foolish woman" (5.2.286). Bosola seems to be the main dramatic agent of this sense of accident, as he changes his mind after killing the Duchess and decides to avenge his own murder by turning against the two brothers, thus suggesting that he made a mistake when he agreed to murder the Duchess. He is also responsible for the disappearance of the main character from the stage in act 4, and thus becomes himself the main character of act 5 , in the absence of the eponymous heroine. Act 5 
could be seen as Bosola's attempt to correct the errors he made in the rest of the play, and thus somehow undo what he did, as he suggests at the end of 5.2:
Well, good Antonio,
I'll seek thee out, and all my care shall be
To put thee into safety from the reach
Of these most cruel biters that have got
Some of thy blood already. It may be
I'll join with thee in a most just revenge.
$(5.2 .338-43)$

Bosola does not hesitate to contradict himself and to take the defence of those he was hitherto supposed to seek out and kill. He is, after all, responsible for the "blood" he mentions here, and we can infer that his action in the play, before or after this change, is fraught with error, since this attempt triggers a new series of mistakes, thus showing that the play is indeed a tragedy of errors: the more the characters try to correct them, the more they are confirmed. The end of the play seems to be devoted to his acknowledgement of a certain number of mistakes: his "direful misprision" (5.4.77), accomplished "unwittingly" (5.5.38), in a word, a "mistake" (5.5.93). For that matter, the plot could be seen as having no sense of directionthat is to say, it does not follow a straight line, a theme that one finds in the Latin root of the word "direction" (directio) - and as following the chance meanderings of the characters instead.

Bosola's part in the play also questions the theme of revenge. The play has sometimes been called a revenge tragedy, ${ }^{11}$ even though its relation to what is considered to be the most famous of the genre, Thomas Kyd's Spanish Tragedy (c. 1582-1592), often borders on the parodic. In fact, Webster questions and remaps the model of the revenge tragedy - which by then had already been deeply questioned, for instance in Marston's Antonio's Revenge (1601), Chapman's Revenge of Bussy d'Ambois (1613) or Shakespeare's Hamlet (c. 1602). Even though the genre had undergone a few variations, such as the impossibility of revenge (in The Revenge of Bussy d'Ambois) or revenge having to wait for God to punish the murderer (in Tourneur's Atheist's Tragedy), Webster goes quite far in his reinterpretation of the theme of revenge as a basis for a tragic plot: he blurs the moral structure of the play and makes it difficult to situate the "error" — that is, the original murder - of the revenge play. More generally, even as a "simple" tragedy, the play makes it difficult to define a sense of hamartia, and even the tragic heroine disappears after the fourth act, while Bosola seems to take over as a tragic character, if not a tragic hero.

That is why Bosola is the main provider of tragic knowledge in the play, but in a rather erratic way. First, he constantly reminds the characters of the play-and its spectators - of the absence of meaning. Being the character that, presumably, gives the Duchess her sense of "direction" (3.2.299), he appears, indeed, as the director, or rather the stage-director of her mental torture, organising, for example, the show based on "the artificial figures of Antonio and his children, appearing as if they were dead" (4.1.55. s.d.). However, the show is entirely based on illusion, which confirms that Bosola's message is skewed and that its sense of direction is unreliable. The Duchess confirms that she is aware of this illusory situation, when

\footnotetext{
${ }^{11}$ Fredson Bowers includes The Duchess of Malfi in his book, Elizabethan Revenge Tragedy, which was the first major work on the subject. However, as he himself points out, Webster's play is quite removed from the Kydian model of The Spanish Tragedy: it "marked the temporary discard of the much modified Kydian plot formula. Webster, together with Fletcher, is the bridge between the older Elizabethans and the so-called decadent drama of Massinger and Ford" (Bowers 178).

${ }^{12}$ Interestingly, at the end of Hamlet, Horatio describes the action of what has just happened on stage as "more mischance / On plots and errors" (5.2.378-9).
} 
she mentions a "tedious theatre" in which she plays "a part" against her will (4.1.81-82) —not to mention Ferdinand describing her as "plagu'd in art" (4.1.108). And indeed, Bosola does provide for tragic knowledge at the moment of the Duchess's death, but hints that absence of knowledge characterises her tragedy. As an ars moriendi, a preparation for death, he prefers to remind her that her knowledge is flawed and that she has no power over her fate. Comparing her to a lark, he says: "this world is like her little turf of grass, and the heaven o'er our heads, like her looking-glass, only gives us a miserable knowledge of the small compass of our prison" (4.2.120-123). This "miserable knowledge" seems to be the leitmotiv of Bosola's "direction," as he keeps harping on the insignificance of life. ${ }^{13}$ Down to the last scene of the play, he reiterates the idea of emptiness: "We are only like dead walls, or vaulted graves, / That ruin'd, yield no echo" (5.5.95-96). The negative structure of the last line confirms the notion of a message of error, one that has missed its aim and is unable to carry out any significant kind of knowledge.

Tragic knowledge is thus doubly flawed: it is acquired by accident, through ignorance and error, and its content is itself "miserable," insignificant. This sense of emptiness is corroborated by other characters at the end of the play, even after the Duchess has died; Antonio's dying speech is an evocation of the vanity of life, with its characteristic reference to bubbles, a frequent symbol in baroque vanitas paintings of the $17^{\text {th }}$ century ${ }^{14}$ :

In all our quest of greatness,

Like wanton boys whose pastime is their care,

We follow after bubbles, blown in th'air...

(5.4.63-64)

Those lines, which are reminiscent of Gloucester's in King Lear ("as flies to wanton boys are we to the gods; they kill us for their sport" (King Lear, 4.1.36-37), express the same sense of emptiness, and of a life that is a "mis-take" according to Bosola, that is to say, a life that has been wrongly taken. Even Ferdinand falls into the sententia mode as he dies and expresses the same notion of greatness being subjected to an erratic sense of direction: "Whether we fall by ambition, blood, or lust, / Like diamonds, we are cut with our own dust" (5.5.70-71).

Far from being a faulty tragedy, The Duchess of Malfi is a play that integrates the notion of error into the tragic process itself, making it both the medium and the content of the tragic knowledge that is acquired at the end of the play. As the idea of a tragic error, an hamartia, seems to have been drowned out by the general atmosphere of corruption, so tragic knowledge is informed by that absence. The play never gives the spectators or readers specific answers, but on the contrary stresses the impression that any kind of action is susceptible to error. In that sense, Webster's play is a modern tragedy: the Duchess is only a part of it. As she disappears from act 5 and Bosola seems to take over her part, we realise that error is a shared kind of tragedy, part of human destiny. At the same time, the form of the play itself is erratic. As François Rigolot wrote, error in the early modern period was also "a textual matter of aesthetics" (Rigolot 1232). Webster's aesthetics, in keeping with the dramatic models of the Jacobean period, did not rely on good proportion and regularity. In his essay "Of Beauty," Francis Bacon had expressed the idea that beauty can be enhanced by imperfection: "There is no excellent beauty, that hath not some strangeness in the proportion" (Bacon 129). In a way, Webster's tragedy also abides by the principle that beauty only appears through errors. It corresponds to Ferdinand's definition of his sister's beauty, as forever illusory: "Methinks her fault and beauty / Blended together, show like leprosy, / The whiter, the fouler" (3.3.62-64).

\footnotetext{
${ }^{13}$ See also 4.2.115-7; 5.4.52-53; 5.5.95-96.

${ }^{14}$ On the baroque aesthetics of the play, see Gisèle Venet, Introduction to The Duchess of Malfi / La Duchesse d'Amalfi (Cottegnies, Laroque, Maguin 1713-1715); see also Gheeraert-Graffeuille.
} 